\title{
Sosialisasi dan Pelatihan Internet Marketing Bagi UMKM Sokasi di Desa Tigawasa
}

\author{
A.A. Istri Ita Paramitha1, Gede Surya Mahendra², I Made Artana ${ }^{3}$ \\ ${ }^{1}$ Program Studi Teknik Informatika, STMIK Primakara,Indonesia \\ ${ }^{2}$ Program Studi Teknik Informatika, STMIK STIKOM, Indonesia \\ ${ }^{3}$ Program Studi Sistem Informasi, STMIK Primakara, Indonesia
}

\begin{abstract}
ABSTRAK
Desa Tigawasa merupakan pusat berbagai kerajinan anyaman bambu seperti kerajinan "Sokasi”. Dari sejumlah kerajinan tersebut, kerajinan "sokasi" merupakan ciri khas yang unik dan sekaligus menjadi kerajinan andalan di Desa Tigawasa. Keunikan pada kerajinan "sokasi” terletak pada corak dekoratif khas Bali dengan ciri ungkap khas Buleleng yang merupakan kepribadian seni kerajinan Tigawasa. Usaha Ibu Ni Ketut Sumiyani dimulai sejak tahun 2002 sampai dengan saat ini. Awalnya usaha kerajinan "Sokasi" ini dirintis Bersama keluarga dan dibantu oleh empat orang pekerja. Usaha yang dilakoni oleh Ibu Ni Ketut Sumiyani mengalami pasang surut dikarenakan banyaknya persaingan usaha kerajinan sejenis di Desa Tigawasa. Selain itu minimnya pengetahuan mitra tentang teknik produksi, teknik pemasaran, pengemasan dan variasi desain produk merupakan faktor yang menyebabkan terjadinya penurunan hasil produksi. Perekonomian keluarga Ibu Ni Ketut Sumiyani sangat bergantung dari hasil produksi usaha kerajinan "Sokasi" ini sebagai satu-satunya sumber pendapatan. Permasalahan yang saat ini dialami mitra yaitu teknik pemasaran yang masih secara tradisional yaitu dengan menitipkan produk kepada pengepul dan hanya mengerjakan produk sesuai pesanan, serta penyebaran informasi juga dilakukan secara konvensional yaitu menyebarkan informasi dari mulut ke mulut. Solusi yang ditawarkan untuk mitra pelatihan internet marketing seperti cara pembuatan akun bisnis, sosial media dan marketplace. Hasil atau luaran yang dicapai dalam kegiatan pengabdian masyarakat ini adalah meningkatnya kemampuan mitra dalam menggunakan teknologi untuk pemasaran.
\end{abstract}

Kata Kunci : Pelatihan, Internet, Markrting, Sakasi, Tigawasa.

\section{PENDAHULUAN}

Desa Tigawasa adalah sebuah desa tua (Bali Aga) yang terletak di daerah pegunungan, di Kecamatan Banjar kabupaten Buleleng, Propinsi Bali, Desa Tigawasa berjarak $20 \mathrm{~km}$ dari kota Singaraja (Profil desa Tigawasa, tahun 2011). Desa Tigawasa merupakan pusat berbagai kerajinan anyaman bambu seperti kerajinan "Sokasi". Dari sejumlah kerajinan tersebut, kerajinan "sokasi" merupakan ciri khas yang unik dan sekaligus menjadi kerajinan andalan di Desa Tigawasa. Keunikan pada kerajinan "sokasi" terletak pada corak dekoratif khas Bali dengan ciri ungkap khas Buleleng yang merupakan kepribadian seni kerajinan Tigawasa. Jenis produk kerajinan anyaman bambu "sokasi" yang dihasilkan oleh kelompok maupun masyarakat di Desa Tigawasa antara lain: tempat nasi, tempat sarana upacara berbagai bentuk, hiasan dinding, hiasan lampu, tas cantik, tempat tisu, tempat kue dengan gaya pokok dekoratif dan gaya latar belakang adalah gaya naturalis . Produk ini dapat dipesan oleh konsumen dengan berbagai design, pilihan warna dan motif anyaman yang berbeda sehingga konsumen yang melakukan pre-order akan mendapatkan produk custom yang berbeda dengan orang lain, sehingga kesan limited-edition menjadikan sokasi sebuah produk yang eksklusif [1].

Ibu Ni Ketut Sumiyani merupakan mitra dalam kegiatan pengabdian masyarakat ini. Usaha Ibu Ni Ketut Sumiyani dimulai sejak tahun 2002 sampai dengan saat ini. Awalnya usaha kerajinan "Sokasi" ini dirintis Bersama keluarga dan dibantu oleh empat orang 
karyawan. Usaha yang dilakoni oleh Ibu Ni Ketut Sumiyani mengalami pasang surut dikarenakan banyaknya persaingan usaha kerajinan sejenis di Desa Tigawasa. Selain itu minimnya pengetahuan mitra tentang teknik produksi, teknik pemasaran, pengemasan dan variasi desain produk merupakan faktor yang menyebabkan terjadinya penurunan hasil produksi. Perekonomian keluarga Ibu Ni Ketut Sumiyani sangat bergantung dari hasil produksi usaha kerajinan "Sokasi" ini sebagai satu-satunya sumber pendapatan.

Proses pemasaran produk yang saat ini dilakukan masih menggunakan sistem tradisional yaitu menitipkan produk kepada pengepul dan hanya mengerjakan produk sesuai pesanan. Penyebaran informasi juga dilakukan secara konvensional yaitu menyebarkan informasi dari mulut ke mulut. Pesanan dari konsumen merupakan target pasar utama dari mitra, karena memberikan profit yang secara signifikan lebih tinggi dari produksi massal yang diberikan kepada pengepul, sehingga mitra lebih dapat mendapatkan manfaat ekonomis yang lebih baik dari pesanan konsumen, dimana produk pre-order dapat di custom sesuai permintaan konsumen, baik dari segi design, warna, bentuk, dan motif anyaman yang ditawarkan mitra. Sehingga kendala yang terjadi dalam proses pemasaran tersebut konsumen tidak mengetahui informasi jelas tentang tempat produksi dan jika konsumen berkeinginan untuk membeli kembali produk tersebut tidak dapat menghubungi pengerajin dikarenakan informasi dalam produk yang dikemas tidak tercantum informasi alamat serta nama usaha mitra. Keterbatasan ekonomi mitra juga membuat mitra tidak memiliki lokasi usaha yang strategis untuk pemasaran produk, dan kondisi geografis pegunungan menyulitkan konsumen perorangan untuk datang langsung ke tempat mitra, sehingga mengurangi penetrasi pasar oleh mitra.

Solusi yang diberikan berupa sosialisasi tentang internet marketing disertai pelatihan untuk memanfaatkan sosial media dan marketplace sebagai media pemasaran. Pelatihan yang diberikan meliputi cara membuat akun google bisnis, sosial media (Instagram) dan marketplace (Tokopedia). Indikator capaian dari kegiatan ini adalah untuk meningkatkan kemampuan pemasaran mitra dalam memanfaatkan teknologi internet sebagai media pemasaran. Setelah mengikuti pelatihan yang diberikan mitra diharapkan mampu melakukan pemasaran prodok dengan memanfaatkan internet secara mandiri, sehingga mampu meningkatkan pendapatan dari hasil penjualan yang dilakukan.

\section{METODE PELAKSANAAN}

\section{Metode Penerapan Kegiatan}

Metode pelaksanan kegiatan pengabdian kepada masyarakat ini diuraikan dalam beberapa tahapan. Adapun alur pelaksanaan kegiatan ini dapat dilihat pada Gambar 1. 


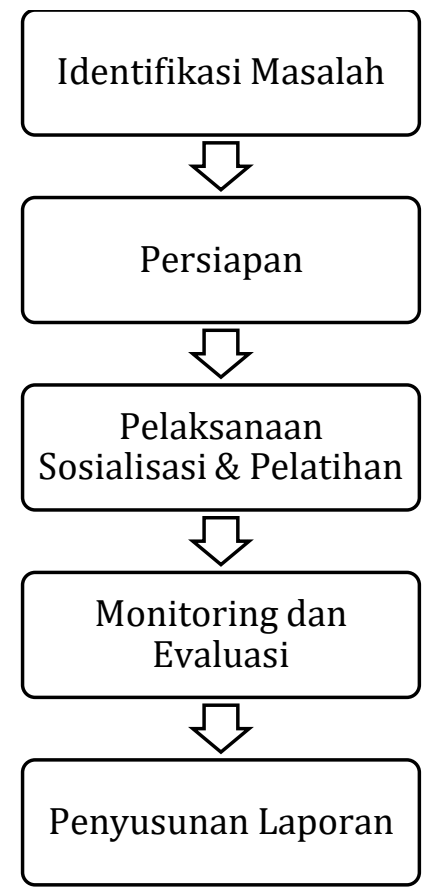

Gambar 1. Alur Pelaksanaan

a. Identifikasi Masalah

Dalam hal ini penulis merumuskan permasalahan yang terjadi yaitu pemasaran dilakukan dengan menitipkan produk kepada pengepul dan hanya mengerjakan produk sesuai pesanan. Penyebaran informasi juga dilakukan secara konvensional yaitu menyebarkan informasi dari mulut ke mulut.

b. Persiapan

Penulis mengumpulkan tim dan menyusun materi terkait dengan pelatihan internet marketing kepada mitra UMKM.

c. Pelaksanaan Sosialiasi \& Pelatihan

Pelaksanaan pelatihan dilaksanakan dalam 4 kali pertemuan seperti berikut:

- Pertemuan pertama, dilakukan dengan memberikan informasi kepada mitra tentang kegiatan pengabdian masyarakat yang akan dilaksanakan. Memberikan pemahaman kepada mitra tentang latar belakang kegiatan dan tujuan kegiatan.

- Pertemuan kedua, memberikan pelatihan pembuatan akun email google my business dan membuat akun Instagram kepada mitra dan pekerjanya.

- Pertemuan ketiga, memberikan pelatihan cara membuat posting produk di akun google my business dan Instagram.

- Pertemuan keempat, memberikan pengenalan dan pelatihan marketplace Tokopedia.

d. Monitoring dan Evaluasi 
Tahap evaluasi yang dilakukan dengan cara observasi di setiap pertemuan.

e. Penyusunan laporan

Penyelesaian laporan sebagai bentuk pertanggung jawaban terhadap pelaksanaan pengabdian masyarakat kepada mitra.

\section{Peserta Pengabdian}

Peserta yang ikut dalam kegiatan pengabdian pada masyarakat ini adalah mitra pemilik UMKM Sokasi Tigawasa.

\section{HASIL DAN PEMBAHASAN}

\section{Hasil Kegiatan}

Kegiatan dilaksanakan dalam empat kali pertemuan yang dilaksanakan pada tanggal $20-24$ Januari 2020 di tempat UMKM mitra, Desa Tigawasa. Pertemuan pertama diberikan sosialisasi mengenai maksud dan tujuan program pengabdian yang dijalankan. Selanjutnya mitra diberikan pelatihan pembuatan akun email google my business mulai dari mendaftarkan akun, melengkapi profil bisnis dan posting foto produk. Pada pertemuan ketiga kemudian diberikan pelatohan dari membuat akun Instagram, melakukan foto produk, membuat postingan produk serta menggunakan hashtag. Pertemuan terakhir yaitu diberikan tentang apa tujuan dan fungsi marketplace, ragam marketplace yang ada di Indonesia kemudian bagaimana membuat akun pada salah satu marketplace terbesar yaitu Tokopedia.

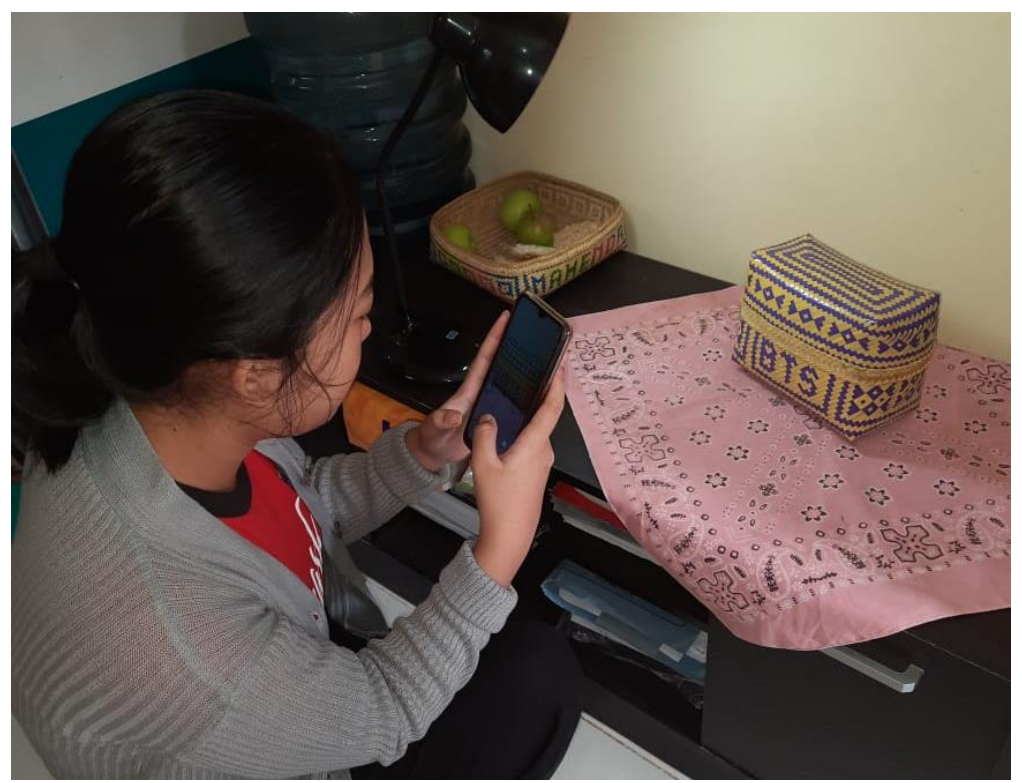

Gambar 2. Pelatihan Pembuatan Akun Instagram 


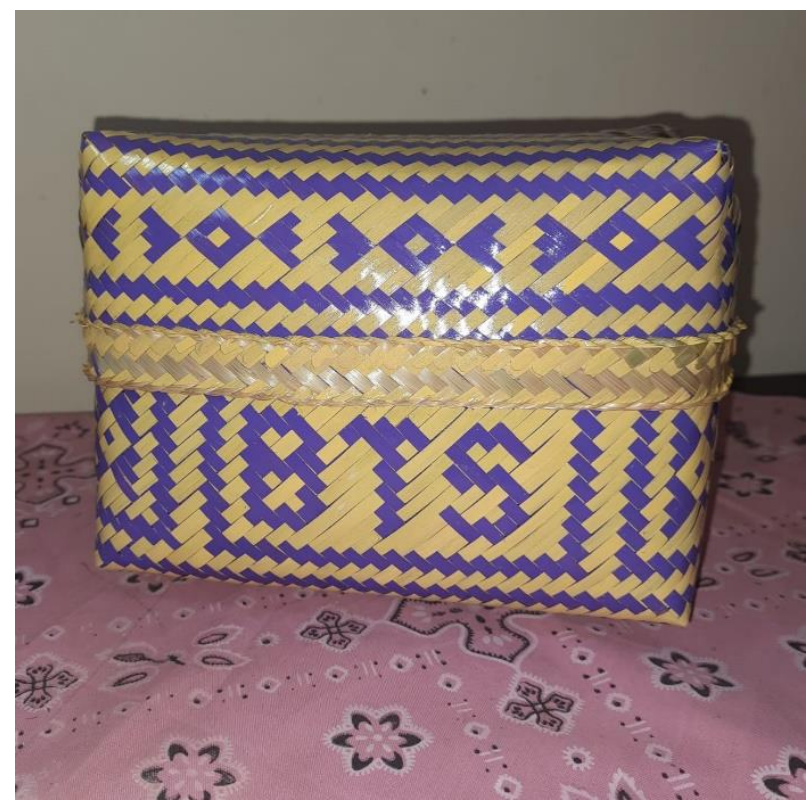

Gambar 3. Salah Satu Produk Sokasi Mitra

\section{Penyelesaian Masalah}

Masalah yang dialami mitra adalah proses pemasaran produk yang saat ini masih menggunakan sistem tradisional. Penyebaran informasi produk yang dengan menyebarkan informasi dari mulut ke mulut sehingga jangkauan konsumen menjadi sangat terbatas. Dengan keterbatasan ini tentunya mengakibatkan pesanan dari konsumen lokal belum cukup memberikan profit yang secara signifikan lebih tinggi. Selain itu, dengan keterbatasan ekonomi mitra juga membuat mitra tidak memiliki lokasi usaha yang strategis untuk melakukan pemasaran produk, dan kondisi geografis pegunungan tempat produksi juga menyulitkan konsumen perorangan untuk datang langsung ke tempat mitra, sehingga mengurangi penetrasi pasar oleh mitra. Oleh karenanya solusi yang diberikan berupa sosialisasi tentang internet marketing disertai pelatihan untuk memanfaatkan sosial media dan marketplace sebagai media pemasaran. Pelatihan yang diberikan meliputi cara membuat akun google bisnis, sosial media (Instagram) dan marketplace (Tokopedia). Seluruh kegiatan sudah dilaksanakan dengan baik dan indicator hasil dari program ini telah tercapai. 


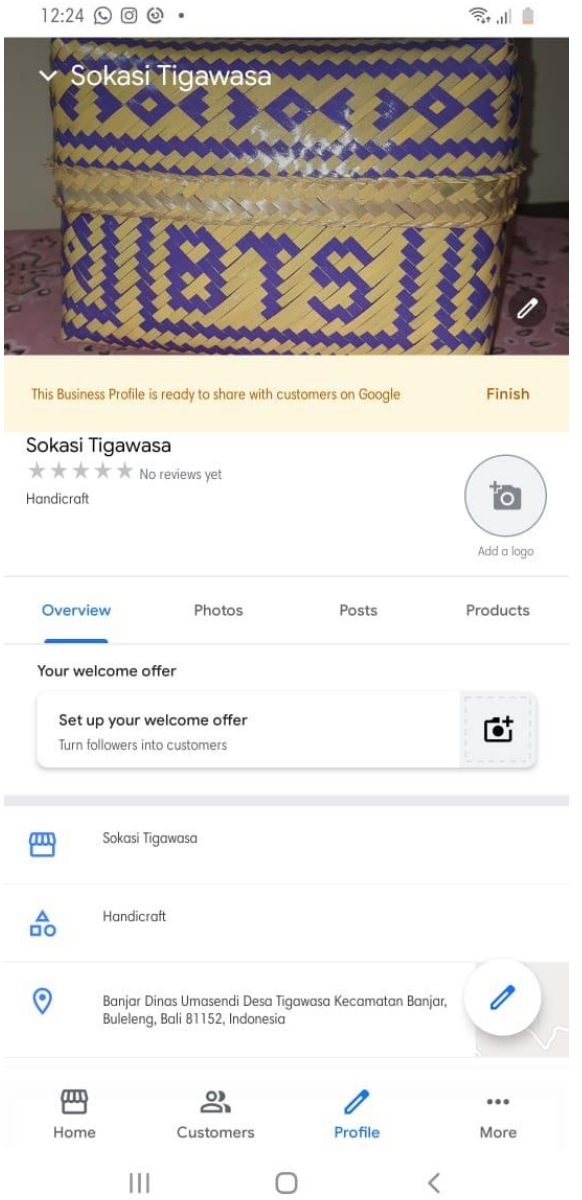

Gambar 3. Indikator Capaian Hasil Pelatihan Pembuatan Akun Google My Business

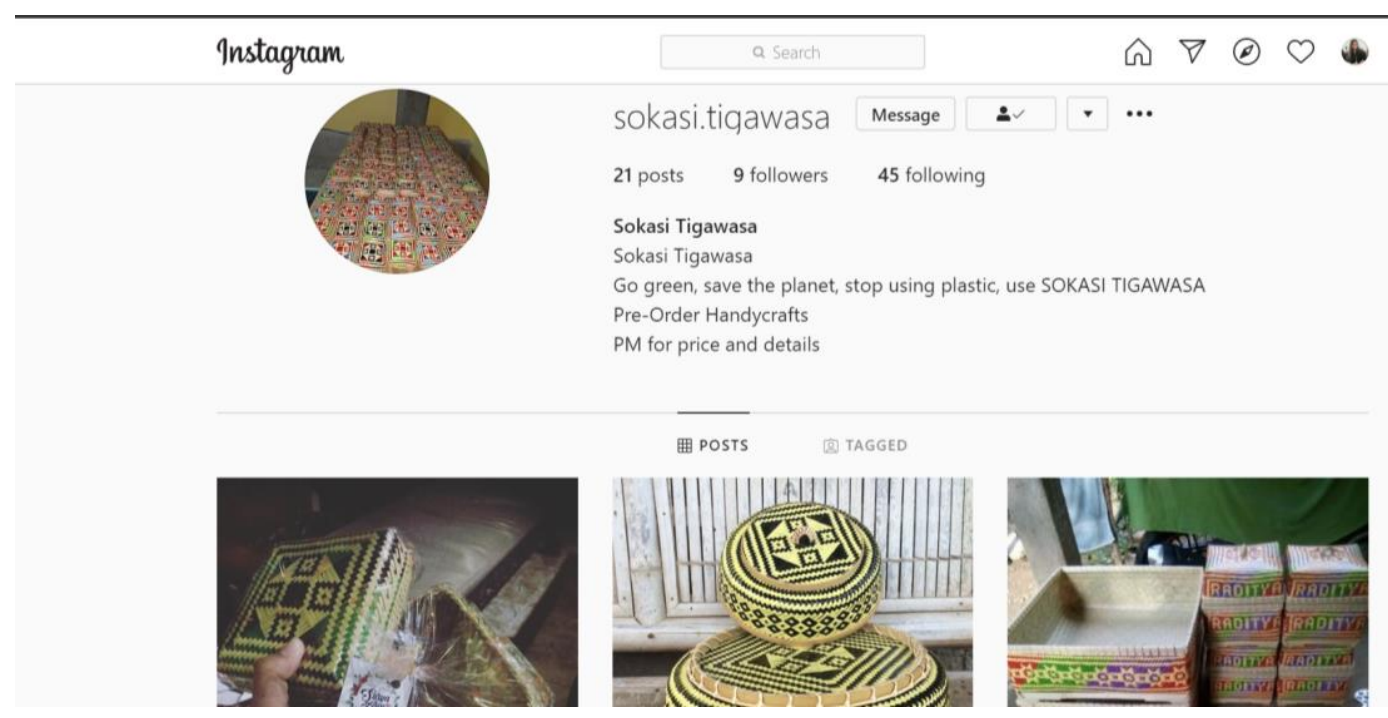

Gambar 4. Indikator Capaian Hasil Pelatihan Sosial Media Instagram 


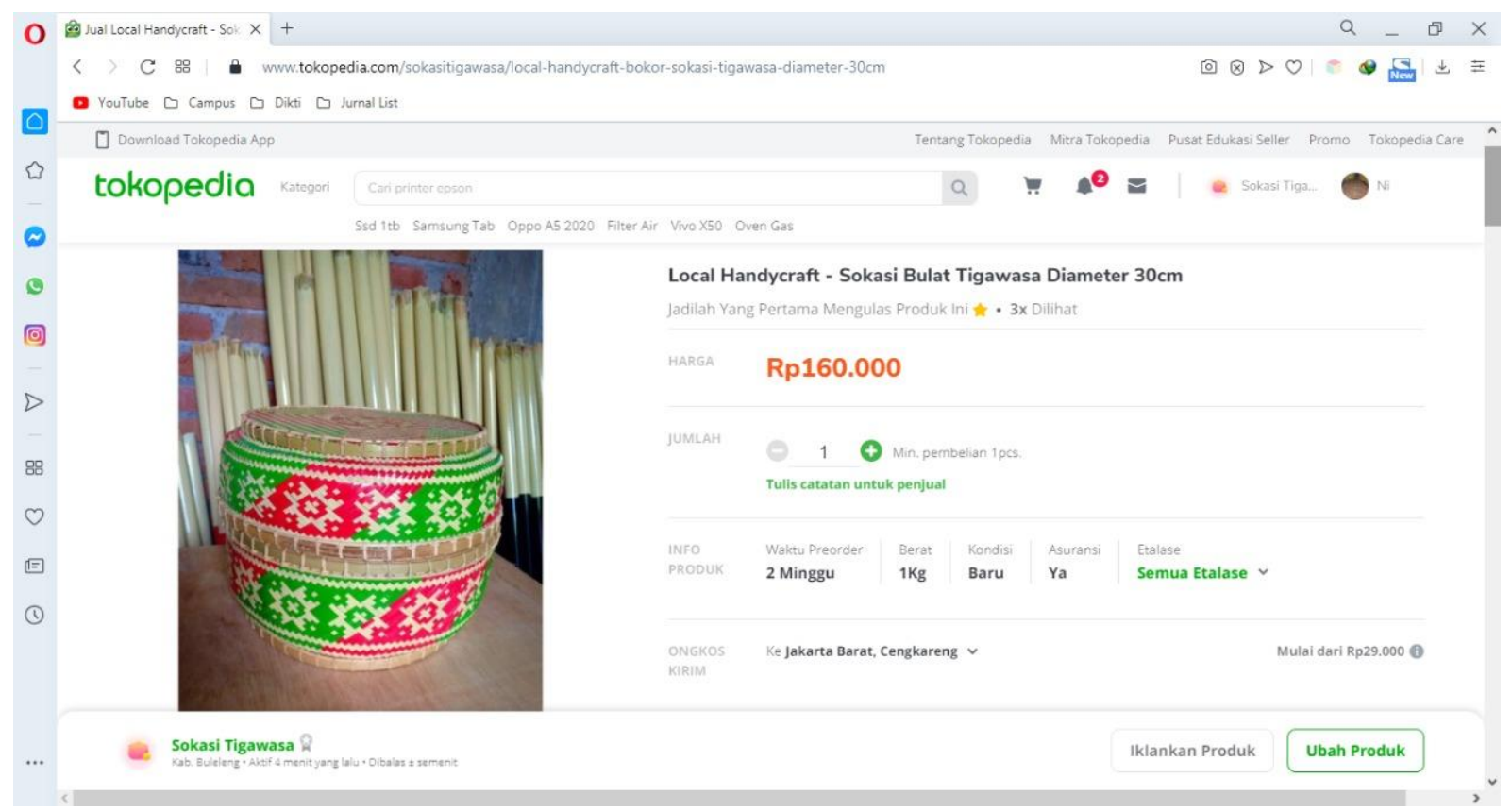

Gambar 5. Indikator Capaian Hasil Pelatihan Marketplace Tokopedia

\section{KESIMPULAN DAN SARAN}

Pelaksanaan kegiatan sosialisasi dan pelatihan internet marketing bagi UMKM Sokasi di Desa Tigawasa sudah terlaksana dan peserta pelatihan sudah mampu menggunakan google my business, Instagram dan Tokopedia. Dalam pelaksanaannya juga diketahui bahwa kegiatan ini mendapatkan tanggapan yang sangat baik dari mitra. Indikator capaian dari kegiatan ini yaitu adanya akun google my business (sokasitigawasa@gmail.com), akun sosial media Instagram (https://www.instagram.com/sokasi.tigawasa/) dan akun marketplace Tokopedia (https://www.tokopedia.com/sokasitigawasa). Selain itu keberhasilan kegiatan ini juga dibuktikan dengan berhasilnya mitra melakukan posting produk pada ketiga akun tersebut.

Diharapkan pelatihan-pelatihan dasar internet marketing yang serupa dapat dilaksanakan untuk meningkatkan kemampuan UMKM di Indonesia. Pelatihan ini dapat membangun kesadaran dan pemahaman pemasaran memanfaatkan internet. Dengan memanfaatkan teknologi dan internet UMKM diharapkan mampu menjadi pusat kekuatan ekonomi bangsa. 


\section{DAFTAR PUSTAKA}

K. Adiputra, I. W. Mudra, and N. P. Muliawati, "Inovasi Dekorasi dan Fungsi Kerajinan Anyaman Besek di Desa Sidetapa Buleleng," PRABANGKARA J. Seni Rupa dan Desain, vol. 22, no. 1, pp. 38-43, 2018.

Kotler and Keller, Manajemen Pemasaran. Jilid I. Edisi ke 13, 13th ed. Jakarta: Erlangga, 2009.

D. N. S. Werastuti and D. S. Wahyuni, "Sistem Informasi Berbasis Web 2.0 Produk Unggulan Usaha Mikro Kecil dan Menengah (UMKM) di Kabupaten Buleleng," Semin. Nas. Ris. Inov., vol. 4, no. 1, pp. 49-58, 2016. 